\title{
COMPUTER SYSTEMS SUPPORTING THE MANAGEMENT OF MACHINES/EQUIPMENT IN HARD COAL MINES. CASE STUDY
}

\author{
Witold BIA $\mathrm{tY}$ \\ Silesian University of Technology \\ Jiri FRIES \\ VŠB-Technical University of Ostrava
}

\begin{abstract}
:
Computer systems supporting the management of machines operation and maintenance in companies have been successfully applied in many branches of industry. Over the last few years these systems have been considerably transformed. It also seems that using them for operating mining machines in hard coal mines is inevitable, as maintenance generates high production costs. If implemented, the systems will allow for optimization of stocks, spare parts and materials, supplies, outsourced services as well as maintenance-repair works. Application of a system supporting the management of mining machines/equipment will also enable a better, more effective use of employees. As a result of these actions, the time needed for preparations and repair will be shortened, which will translate directly into the economic effects of mines.
\end{abstract}

Key words: operation support systems, maintenance, mining industry, mining machines/equipment

\section{INTRODUCTION}

Computer systems supporting the management of machines operation and maintenance have been subject to considerable transformations in recent years $[2,3,10,18]$. On the one hand, this is the effect of ever-increasing requirements on the part of the users, while on the other hand, it results from the development of computer technology, both in terms of equipment capabilities and the ability of operational systems or new platforms $[5,15,17$, 22]. These two factors are inextricably linked and complement each other. The users' requirements pose serious challenges to information technologies, and, at the same time, their development enables the achievement of new goals. In functional terms, systems supporting the management of machines operation and maintenance have evolved from simple CMM programmes (Computerised Maintenance Management system), enabling the maintenance management in a production plant to be put in order, into complex systems that support the management of enterprise assets (EAM - Enterprise Asset Management, SAM - Strategic Asset Management) [10, 11, 12, 23]. They are applied not only in the production area, but also in the broadly understood enterprise infrastructure (Facility Management), IT infrastructure, internal and external transport, supplies of spare parts and materials needed in maintenance management, external contacts etc. [1, 14, 19, 23] (Fig. 1).

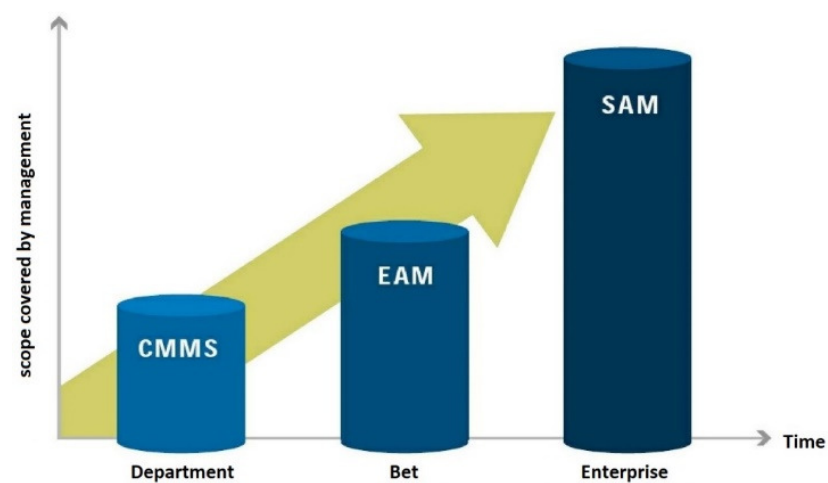

Fig. 1 Development of computer-aided systems of management of operation and maintenance of machines and equipment Source: [21].

The most advanced systems enable actions to be extended to many plants of one enterprise scattered around the world (multi-site, multi-organization), many languages, time zones, currencies etc. With maintenance support systems it is possible to shorten the time and reduce the costs of maintenance as well as guarantee the availability of indispensable parts while reducing the stocks, improving the supplies and streamlining the organization of external contracts $[13,22]$.

Asset management can start before a machine begins to be operated in an organization. A precise list of materials and installation instructions will considerably facilitate the ma- 
chine operation. By creating a visual catalogue of the assets possessed (MAXIMO Illustrated Parts Catalog), according to the description standards accepted throughout the organization (Struxure ${ }^{\mathrm{TM}}$ and Standard Modifier Dictionary $\left.{ }^{\mathrm{TM}}\right)$, the system provides employees with the possibility to move around the structure of the assets supplemented with detailed drawings/diagrams of its elements, and, in consequence, to localize an object, define necessary items to be repaired and identify them in the supply chain $[9,17]$. In the whole cycle of assets functioning in an organization, today's maintenance support systems facilitate activities related to the management of work, planning and scheduling.

The functional development of the systems is inextricably connected with the technical development of the "computer" branch [12, 15, 21]. The proliferation of network systems (Internet, intranet), a growth in their functionality, reliability of operation and security of information sent resulted in the extension of the scope of operation of management support systems to whole organizations. It also enabled creating connections between organizations, by means of which various activities can be carried out, such as supply of parts and materials, contracting of services etc. The functionality of such connections evolved from the level of simple sending of email correspondence into automatic operations, performed without man's participation (but taking place under man's supervision). "Automatic supply" can generate considerable savings. AMR Research, based on analyses conducted by Boston Consulting Group, estimates that among the biggest companies on a global scale, the reduction of supply costs may reach even $60 \%$ [24].

Another factor that exerts a considerable impact on EAM systems is the development of portable IT devices. The common use of such devices "freed" operational employees of a number of office activities, thus contributing to a better use of their time. The diversity of portable computer devices offers the possibility of selecting adequate solutions, adjusted to particular goals. An important feature of the above solutions is their close integration with the main system. Information to and from a portable device can be sent in various ways, depending on the functional connection with the main system (docking cradle), online wi-fi connection, connections through mobile phone networks, dial-up connection, IRDA connection).

The development of computer systems supporting the management of machine operation and maintenance in enterprises must be correlated with the specific requirements of the users. As the systems developed, their "specialization" turned out necessary. Based on the basic functionality, dedicated versions began to be created for:

- production,

- technical infrastructure,

- transport,

- IT infrastructure etc.

The scope of activity is extended by "adding" new components to the system. Which of the activity spheres, which component of the system becomes a leading one for the organization depends solely on its specific character.

The diversity of branches, products and requirements caused that systems dedicated for the production sphere had to develop also in other directions. Systems dedicated for other sectors were also created so as to fulfil the technical and formal requirements characteristic of a particular branch $[2,8,9]$.

\section{ORGANIZATION OF OPERATION-REPAIR WORKS IN THE MINING INDUSTRY}

In Polish hard coal mines, maintenance of mining machinery/equipment is carried out by two subjects (Fig.

2) $[2,3,4,7]$ :

- the user of a particular machine (mine);

- the producer of this machine.

\begin{tabular}{|c|c|c|}
\hline TYPE OF ACTIVITIES & GUARANTEE & AFTER GUARANTEE \\
\hline $\begin{array}{c}\text { Cyclic carried out } \\
\text { operations }\end{array}$ & User/coal mine & User/coal mine \\
\hline $\begin{array}{c}\text { Non-cyclic carried out } \\
\text { operations } \\
\text { "where appropriate" }\end{array}$ & $\begin{array}{c}\text { User/coal mine } \\
\text { (with the agreement of } \\
\text { the manufacturer) }\end{array}$ & User/coal mine \\
\cline { 2 - 4 } & Manufacturer & Manufacturer \\
\hline
\end{tabular}

Fig. 2 Activities during the period of the guarantee and after guarantee

Activities in the facility maintenance area (performed cyclically) have a maintenance and control character - there are no cyclical repairs $[2,3,8,14,16]$. These activities are performed by the mine on its own, no matter whether a machine/device at the moment a need for a particular activity arises is under guarantee or not.

The organization of operation-repair works in Polish hard coal mines is based on procedures aimed at ensuring effective actions, in accordance with the instructions and regulations in force, which enable keeping the mining machines in good working order. Procedures specify the directions, methods and persons implementing the activities undertaken so as to keep the machinery in process lines in good working order. In hard coal mines there is no possibility of shutting down the machinery in order to carry out an overhaul.

When an incident (breakdown) occurs, a service request is created to provide a basis for contact with the company dealing with service requests (the employee specifies the scope of breakdown, its causes, information on potential damage as well as equipment necessary to remove the breakdown).

In this article, an example of a procedure for securing the work of a shearer has been presented. In the pre-emergency state, when there are visible symptoms of a forthcoming breakdown, spare parts are ordered and repair is carried out during the nearest maintenance shift. The diagram of operation in case of breakdown, pre-emergency state or necessity of machine adjustment has been presented in Fig. 3. 


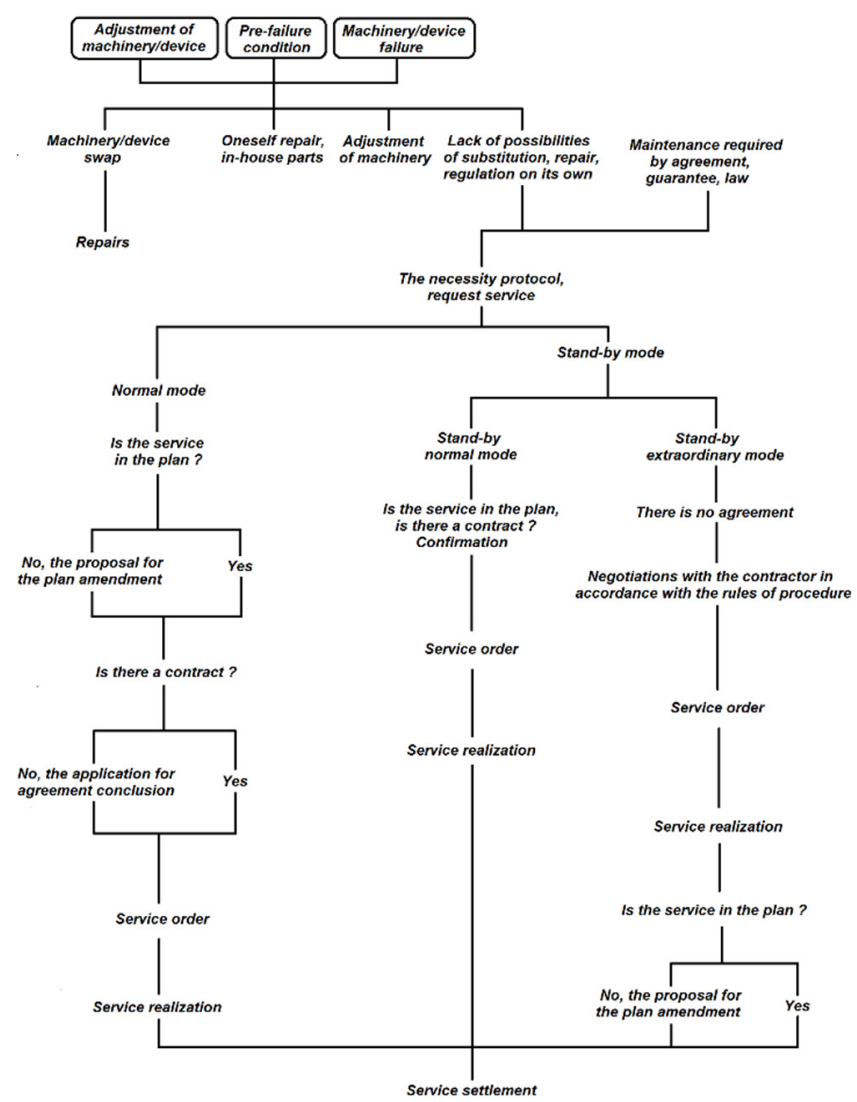

Fig. 3 Procedure in the case of failure, pre-failure, or necessary adjustment of device

\section{MAINTENANCE AND REPAIRS OF A SHEARER}

The schedule of maintenance, adjustment works and checks must comply with the guidelines contained in the shearer's operating instructions and separate instructions for the machine subassemblies. The main requirements to be fulfilled when performing works related to the shearer's operation and repair include:

- promptness of works - terms established by the producer have to be observed,

- staff competence - all works related to operation and repair can only be performed by a properly qualified technical personnel,

- supervision over works - appointment of supervisors for work coordination,

- securing the area - works can only be carried out in a previously secured area,

- securing the shearer - the shearer must be protected against accidental dislocation and prevented from being accidentally turned on,

- application of detailed procedures - technical staff must follow the required procedures for switching on and off, in accordance with the operating instructions and repair works principles,

- use of specialized equipment - in the process of dismantling or installing big elements or whole shearer subassemblies, they must be properly fixed and secured on the lifting equipment.

- following the producer's recommendations - detailed instructions regarding operation and repair works, such as:

- cleaning the shearer before commencing repairs or maintenance works,
- protecting all openings which for safety or operational reasons need to be covered or closed, against the access of water and cleaning agents, before starting to clean the machine, e.g. with a pressurized water jet,

- removing all the covers and plug buttons used for cleaning when it is finished,

- check of tightness of the hull and hydraulic connections,

- checking for loose, used or damaged connections tightening loose screw connections (replacement, if necessary),

- if it is necessary to dismantle protective devices to perform repair or maintenance works, upon completion of works, they have to be immediately placed back and checked for correct functioning,

- removal of materials and used parts in a manner that is safe for the environment,

- carrying out works related to cutting, welding or grinding in a designated area - after obtaining permission,

- performance of works related to hydraulic systems by a competent personnel.

Periodical checks must be conducted to ensure proper operation and failure-free work of the shearer. According to the operating instructions, there are daily, weekly and monthly inspections.

\section{APPLICATION OF A SELECTED CMM CLASS SYSTEM}

The MP2 system [20] is a computerized maintenance management system of CMM class. It is a complete software package for supporting the management of maintenance and technical service teams in small and medium-sized enterprises. It includes both issues related to current maintenance and effective maintenance management. The MP2 
system is equipped with functional tools to support assets management, which make available an analysis of service history and the structure of expenditure incurred for its maintenance. The system serves the management of repairs, maintenance, stocks and supplies as well as the management of human resources. Additionally, MP2 provides efficient and easy-to-use tools for analysis and reporting, making available more than 1000 predefined reports and over 300 charts. The available standard reports and charts can be tailored by the user to the specific needs of an enterprise without a required specialist programming knowledge.

\section{MP2 system modules}

The MP2 system is built of modules, consisting of the following elements:

- facilities,

- work orders,

- planning,

- warehouse,

- purchases,

- work demand,

- human resources,

- administration,

- budget.

„Facilities” module (Fig. 4):

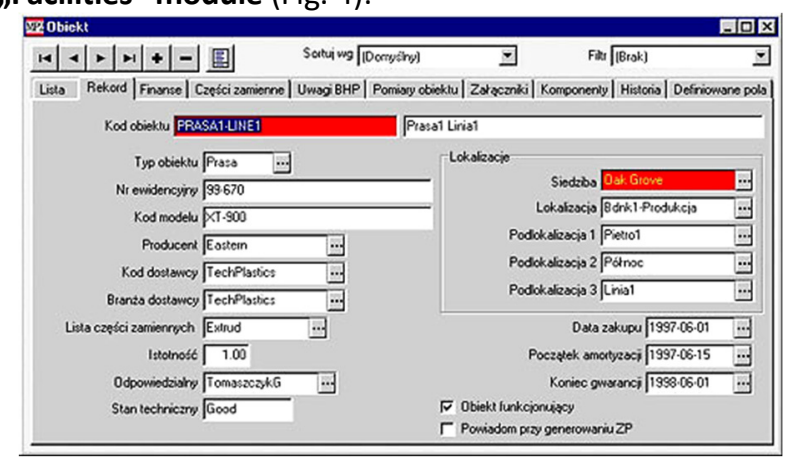

Fig. 4 Screen view that describes the object

- technical records of assets,

- detailed technical parameters of equipment,

- defining the structure of equipment by means of a graphic interface in the form of a tree,

- history of equipment operation,

- possibility of attaching electronic documentation to the facility: CAD drawings, doc files and others, together with scanned documents.

„Human resources” module:

- technical staff work schedule,

- file of employees with detailed data on qualifications, trainings etc.,

- specification of man-hour rates for different professional groups, employees and types of work.

„Work order” module (Fig. 5):

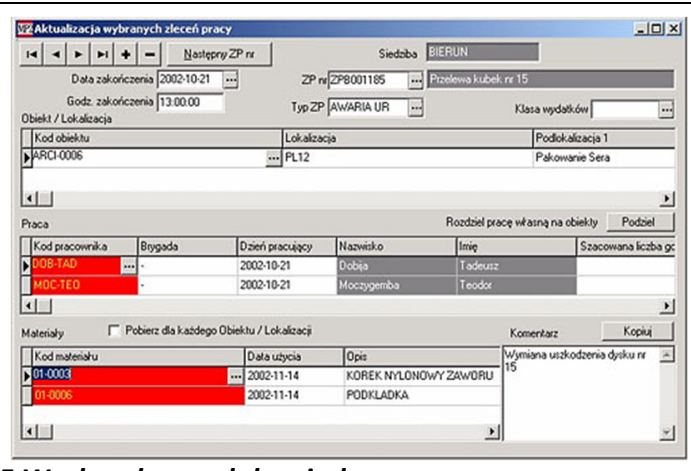

Fig. 5 Work order module window

- creation of work orders consisting of a number of activities carried out by different groups of specialists (professional groups). For each activity the required resources can be defined: time consumption, material resources, outsourced services, as well as service instructions and any comments,

- attaching technical documentation, diagrams, work permits, safety instructions etc. to work orders,

- planning and handling of maintenance-preventive works,

- handling of current works and emergencies,

- handling of service requests,

- analyses as well as technical and financial reporting.

"Warehouse" module:

- management of spare parts and consumables,

- warehouse operations: deliveries, receipts, returns,

- transfers, stock-taking,

- ABC and EOQ analyses,

- analyses of materials turnover based on charts and reports.

„Planning” module (Fig. 6):

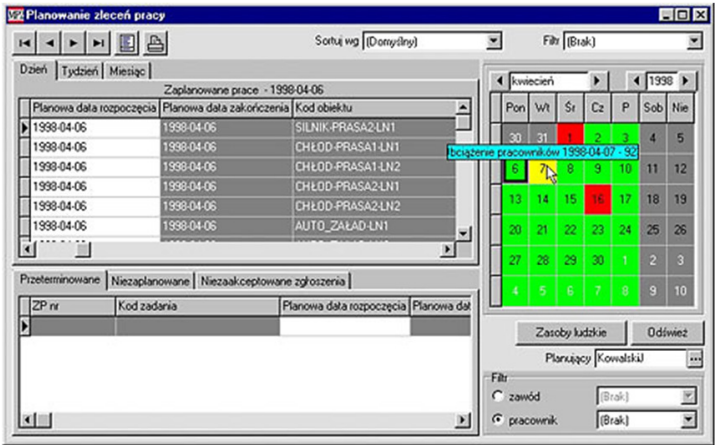

Fig. 6 Work order planning

- management of maintenance staff work schedule by planning and supervising the ordered works,

- planning and optimization of workload,

- handling of periodical activities - checks, inspections, tests etc.

- time and operation planning.

„Purchase" module:

- handling of full supply cycle: demand, requests for quotation, orders,

- purchase authorization mechanisms,

- implementation of purchases based on planned works and consumption,

- estimation of minimal stocks - also on the basis of $A B C$ and EOQ analyses,

- inventory turnover analyses. 
„Work demand (order)" module (Fig. 7):

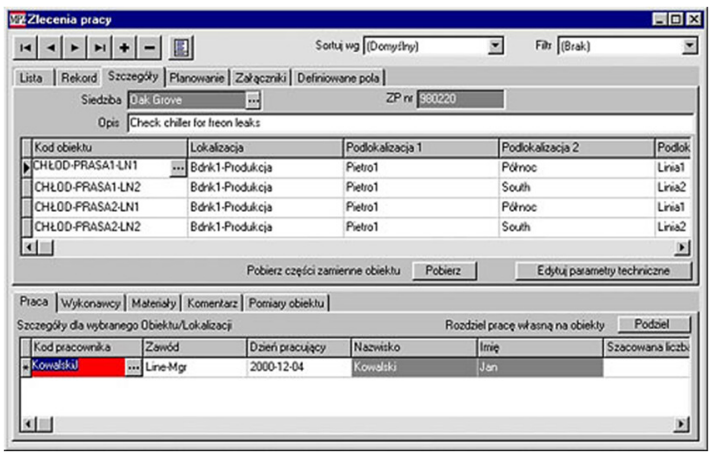

Fig. 7 Works order module window

- prompt reporting of events requiring intervention: breakdowns, repairs etc.

- automatic notification of requests by email or text message,

- current preview of reported issues - implementation status check etc.

\section{„Administration” module}

- user permission management,

- configuration of user interface,

- configuration of system data structures and many system functions.

\section{„Budget" module:}

- planning of budgets for implemented work orders and bigger projects,

- specification of the budget structure by costs, periods etc.,

- budget implementation monitoring,

- analyses and reporting.

The MP2 system is a solution for industrial maintenance service teams. It can be applied wherever the key issue is to ensure uninterrupted work [21].

Facility maintenance in industry is a crucial issue. A production line breakdown entails various costs. Apart from losses resulting directly from shutdowns, they among others include the costs of service teams, the purchase and storage of parts and repairs. An evaluation of fixed assets maintenance costs is an important issue for the organization management. An analysis of the causes and effects of breakdowns may turn out to be even more important.

A key to the success of actions aimed at reducing the maintenance costs of fixed assets is systematic collection of data and their analysis. In MP2 one can define any number of facilities and put them in hierarchical order - production halls can be assigned to a building, machines or their groups can be assigned to production houses; functional subsystems and specific subassemblies can be identified in machines, e.g. bearings. Each facility can be granted a unique number and name, and a file in any format can be assigned to it, e.g. documentation, photograph, animation etc. A facility is assigned with features related to its use - strength, critical conditions, terms of periodical inspections.

The system also stores the history of the facility's failure frequency - the dates of breakdowns, causes, effects, costs of materials and repairs. The stored data allows creating a "database of knowledge" on breakdowns and manners of coping with them. It enables conducting detailed analyses, e.g. comparisons of the strength of parts from different suppliers, and even comparisons of the effectiveness of service technicians' work. Based on the set parameters and failure frequency history, the MP2 application "predicts" when a specific part will break down, and "prompts" an inspection or replacement in due time. The system can also define optimal stocks and issue automatic missing elements' purchase orders.

The MP2 system structure also contains mechanisms of planning and management of maintenance service teams' work. Work orders can be issued manually or automatically, at any time in advance, by assigning a particular person, time and parts to a task. They can be transferred to relevant persons by email or on a pager. The MP2 system was not prepared for a particular branch of industry. It is versatile enough to support maintenance of any system, e.g. a hotel, powerhouse, mining plant (hard coal mine) or a supercomputer.

\section{CONCLUSIONS}

Application of a CMM class system in an enterprise brings a number of benefits, such as:

- inventory of technical facilities,

- overhaul management,

- maintenance management,

- service works management.

Implementation of the above functionalities enables:

- inventory and management of company's fixed assets,

- minimization of unplanned downtimes of machines and equipment through prevention of breakdowns,

- improvement of production continuity,

- extending the life of machines and equipment,

- optimizing the management of spare parts and consumables,

- planning and analysis of resources operating costs.

Owing to this, it is possible to:

- reduce the costs of production, which translate into profitability increase,

- reduce the costs of storage and transport by optimizing the stocks,

- reduce the costs related to failures and repairs,

- increase the production capacity of an enterprise,

- extend the life cycle of machines and equipment,

- decrease the duration of downtimes caused by failures,

- improve management related to better and faster information,

- improve safety and reduce the number of accidents,

- minimize labour input for creating traditional documentation.

Excessively frequent breakdowns do not appeal to our imagination, and, in consequence, seem to be merely something that in a way is incorporated in the essence of equipment use. Therefore, it is worth predicting in advance the possibility of certain incidents or situations to occur, so that they can be effectively prevented. Facility maintenance departments often intervene only after a breakdown occurred, without having appropriate spare parts or even emergency procedures. In such a case, a CCM system seems to be irreplaceable and worth implementing. An equally significant aspect related to facility maintenance is Machine Directive, which imposes new duties on machine 
and equipment users, related mainly to record keeping. What is also important, it forces considerable care for machinery stock.

Proper selection of shearers adjusted to the existing geological-mining conditions or mining-technical condition in mines is also a very important issue. For this reason, it is necessary to conduct investigations into mechanical properties of coals so that mining machines can be adequately selected in order to ensure proper mining and reduce the failure frequency of machines and equipment used for coal deposits exploitation [6].

\section{ACKNOWLEGEMENT}

This article was prepared within the statutory research titled "Development of intelligent production methods as well as work and life environments in the context of production engineering challenges" work symbol 13/030/BK_18/0039 performed at Silesia University of Technology, Institute of Production Engineering.

\section{REFERENCES}

[1] Antosz K, Stadnicka D. Evaluation measures of machine operation effectiveness in large enterprises: study results. $E k$ sploatacja i Niezawodnosc - Maintenance and Reliability 2015; 17 (1): 107-117, https://doi.org/10.17531/ein.2015.1.15.

[2] Biały W., Rozmus M.: Możliwości zastosowania narzędzi komputerowych w serwisowaniu maszyn górniczych. Mechanizacja i Automatyzacja Górnictwa nr 11/2005, Katowice 2005. ISSN 0208-7448.

[3] Biały W., Bobkowski G., Konderla J.: Wspomaganie eksploatacji maszyn i urządzeń górniczych z wykorzystaniem komputerowych systemów CMMs. Mechanizacja i Automatyzacja Górnictwa nr 6(425)/2006. ISSN 0208-7448.

[4] Biały W., Bobkowski G.: Application of computer systems in supporting maintenance policy in mining industry. Kwartalnik naukowy: Organizacja i Zarzqdzanie nr 4(8)/2009. Gliwice 2009. ISSN 1899-6116.

[5] Biały W., Bobkowski G.: Computer instruments in mining machinery maintenance. Technická Diagnostika. z.1 ročnik XVI 2007. ISSN 1210-311X.

[6] Biały W.: The selection of optimal method determining mechanical properties of coal layers. Management Systems in Production Engineering 4/2011. ISSN 2083-5280. pp. 26-30.

[7] Bobkowski G., Konderla J., Biały W.: Wykorzystanie systemów komputerowych w zarządzaniu gospodarką remontową zakładów górniczych. Ekonomika i Organizacja Przedsiębiorstwa nr 7/2006. ISSN 0860-6846

[8] Brodny J, Stecuła K, Tutak M. Application of the TPM strategy to analyze the effectiveness of using a set of mining machines. Albena: $16^{\text {th }}$ International Multidisciplinary Scientific GeoConference. SGEM2016; Book 1: Science and Technologies in Geology, Exploration and Mining: pp. 65-72.

\footnotetext{
Witold Biały

Silesian University of Technology

Faculty of Organization and Management

Institute of Production Engineering

ul. Roosevelta 26, 41-00 Zabrze, Poland

e-mail: witold.bialy@polsl.pl

ORCID ID: 0000-0003-2313-0230
}

[9] Jasiulewicz-Kaczmarek M. Practical Aspects of OEE in Automotive Company - Case Study. Guilin: Proceedings of the 2016 International Conference on Management Science and Management Innovation; 2016; Book Series: AEBMR-Advances in Economics Business and Management Research: 213-218, https://doi.org/10.2991/msmi-16.2016.51.

[10] Loska A.: Selected organizational aspects of maintenance organization modeling. Management Systems in Production Engineering 4/2011, Gliwice 2011. ISSN 2083-5280.

[11] Loska A. Scenario modeling exploitation decision-making process in technical network systems. Eksploatacja $i$ Niezawodnosc - Maintenance and Reliability 2017; 19 (2): 268-278, http://dx.doi.org/10.17531/ein.2017.2.15.

[12] Loska A. Remarks about modelling of maintenance processes with the use of scenario techniques. Eksploatacja $i$ Niezawodnosc - Maintenance and Reliability 2012; 14 (2): pp. 92-98.

[13] Loska A. Methodology of variant assessment of exploitation policy using numerical taxonomy tools. Management Systems in Production Engineering 2/2015. ISSN 2299-0461. DOI 10.12914/MSPE-09-02-2015. pp. 98-104.

[14] Legutko S. Development trends in machines operation maintenance. Eksploatacja i Niezawodnosc - Maintenance and Reliability 2009; 2(49): 8-16.

[15] Levitt J. The Handbook of Maintenance Management. New York: Industrial Press Inc., 1997.

[16] Moubray J. RCM II - Reliability Centered Maintenance. Oxford: Elsevier Ltd., 2007.

[17] Puchała W., Biały W., Bobkowski G.: Możliwości zastosowania komputerowych systemów wspomagających zarządzanie eksploatacją maszyn i urządzeń. Zeszyty Naukowe Akademii Morskiej w Szczecinie z. nr 5(77) 2005. ISSN 17338670.

[18] Puchała W., Bobkowski G., Biały W.: Systemy wspomagające zarządzanie utrzymaniem ruchu w przemyśle polskim. Ekonomika i Organizacja Przedsiębiorstwa nr 7/2006. ISSN 0860-6846

[19] Puchała W., Biały W., Bobkowski G.: Kierunki rozwoju komputerowych systemów wspomagających zarządzanie eksploatacją maszyn i urządzeń. Wydawnictwo "ORGMASZ”. Ekonomika i Organizacja Przedsiębiorstwa 7/2005, Warszawa 2005. ISSN 0860-6846

[20] http://www.e2000.com.pl/MP2_cechy_systemu.aspx

[21] http://www.computerworld.pl/artykuly/282897 /Dmuchac.na.zimne.html

[22] Rich MacInnes, Stephen Pearce, Strategic MRO, powered by DSC, Net Results, Inc. 2002.

[23] "Strategic MRO, powered by DSC" - Rich Maclnnes, Stephen Pearce - Net Results, Inc. 2002.

[24] AHR Research Raport, "Strategic Socercing Gets and E", 2001.

\section{Jiri Fries}

VŠB-Technical University of Ostrava

Department of Production Machines and Design

17.listopadu 15, 70833 Ostrava-Poruba, Czech Republic

e-mail: jiri.fries@vsb.cz

ORCID ID: 0000-0001-9776-6878 